\title{
Record of Rhabdostyla chironomi Kahl, 1933 (Ciliophora, Peritrichia) Epibiont on Chironomidae larvae (Diptera, Chironomidae) in a lotic sytem in Brazil
}

\author{
Dias, RJP. * Cabral, AF. ${ }^{\mathrm{a}}$, Stephan, NNC. ${ }^{\mathrm{a}}$, Martins, $R T .^{\mathrm{a}}$, \\ Silva-Neto, ID. ${ }^{\mathrm{b}}$, Alves, $R G .{ }^{\mathrm{a}}$ and $D^{\prime}$ Agosto, $M{ }^{\mathrm{a}}{ }^{\mathrm{a}}$ \\ aPrograma de Pós-graduação em Comportamento e Biologia Animal, Instituto de Ciências Biológicas - ICB, \\ Campus Universitário, Universidade Federal de Juiz de Fora, \\ CEP 36036-900, Juiz de Fora, MG, Brazil

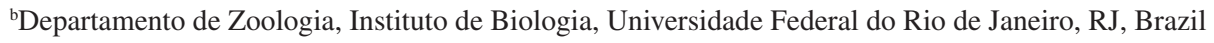 \\ *e-mail: rjuniodias@hotmail.com \\ Received October 6, 2006 - Accepted January 10, 2007 - Distributed November 30, 2007
}

(With 2 figures)

Epibiosis is a facultative association of two organisms: the epibiont and the basibiont. The term "epibiont" includes organisms that, during the sessile phase of their life cycle, are attached to the surface of a living substratum, while the basibiont lodges and constitutes a support for the epibiont (Wahl, 1989; Fernandez-Leborans and Tato-Porto, 2000).

Several ciliate protozoans live as epibionts on animals and plants, using them as substrate (Fenchel, 1987; Sleigh, 1988; Mayén-Estrada and Aladro-Lubel, 2001). Most ciliates of the genus Rhabdostyla Kent, 1880 (Peritrichia, Epistylidae) live as epibionts of freshwater invertebrates, such as rotifers, crustaceans (cladocerans, copepods), insects from the orders Ephemeroptera and Diptera (Chironomidae), and annelids (Oligochaeta and Polychaeta) (Kahl, 1935; Precht, 1935; Nenninger, 1948; Fernandez-Leborans and Tato-Porto, 2000; RegaliSeleghim and Godinho, 2004). Among species of the genus Rhabdostyla, only $R$. chironomi Kahl, 1933 has been reported on Chironomidae larvae. This species was found on the respiratory tubes of chironomids in a brackish water pond at Kiel, Germany (Kahl, 1935). Chironomids of the genus Chironomus Meigen, 1803 (Diptera, Chironomidae) present a wide geographical distribution, living in lentic or lotic environments. Their wide distribution and great abundance in various freshwater ecosystems is explained by their several larval stage adaptations (Armitage et al., 1995).

During a survey of ciliated protists and benthic macroinvertebrates in the São Pedro stream, municipality of Juiz de Fora, MG, Brazil, we report the occurrence of Rhabdostyla chironomi (Figure 1) on larvae of Chironomus decorus Johannsen, 1905. Samples were taken from the sediment from September 2005 using a Van Veen grab in a collection station of the São Pedro stream $\left(21^{\circ} 45^{\prime} \mathrm{S}\right.$ and $\left.43^{\circ} 21^{\prime} \mathrm{W}\right)$, basin of the river Paraibuna, within the urban region, at a point where domestic sewage is directly discharged. The sediment samples were fixed in $8 \%$ formaldehyde until the moment of washing in a $210 \mu \mathrm{m}$ mesh sieve. After selection, the larvae of Chironomus were preserved in $70 \%$ alcohol and mounted on slides with lactophenol, and further investigated for epibiont ciliates through bright field and differential interferential contrast microscopy (DIC). We monitored the physical and chemical qualities of the water recording the dissolved oxygen concentration, $\mathrm{pH}$, conductivity and water temperature. The autecological data registered for $R$. chironomi were $5.19 \mathrm{mg} . \mathrm{L}^{-1} \mathrm{O}_{2}, \mathrm{pH}$ 8.24, $161 \mu \mathrm{S} . \mathrm{cm}^{-1}$ and $21.2^{\circ} \mathrm{C}$.

This new record of $R$. chironomi in a stream seems to be the first since its description in 1933 on chironomid larvae in a brackish water pond, according to the literature revision. In Brazil, R. pristinis Righi, 1973 species were recorded on Pristina minuta (Stephenson, 1914) (Oligochaeta, Naididae), in soil samples collected near the Capivara River in Serra do Cipó mountains (19 30' S and 43 45' W), Minas Gerais (Righi, 1973) and Rhabdostyla sp. on metazooplankton organisms (rotifers, cladocerans and copepods), in a shallow eutrophic artificial reservoir, Monjolinho Resevoir (22 ${ }^{\circ} 01^{\prime} \mathrm{S}$ and $47^{\circ}$ 53' W), São Carlos, São Paulo (Regali-Seleghim and Godinho, 2004).

In the present record, $R$. chironomi species were found on the ventral tubules of the chironomids (Figure 2), as reported in its description. The localization of these ciliates in ventral tubules may be related to the ventilation behavior shown by chironomids. These larvae are apneustics and breathe the oxygen diluted in water through the body surface, mainly through the ventral and anal tubules. Furthermore, they generate ventilation flows by moving their posterior end expansions (tubules) or through a swimming behavior, which are means that favor respiratory exchanges (Merritt and Cummins, 1984).

Another important aspect of the epibiotic relationship among ciliated protists and larvae of Chironomus is its possible use as organic pollution indicators. Representatives of the genus Chironomus as well as several peritrich ciliates present high abundance in organically enriched environments (Henebry and Ridgeway, 1979; Armitage et al., 1995). Rhabdostyla inclinans Roux, 1901 is the only species of the genus 

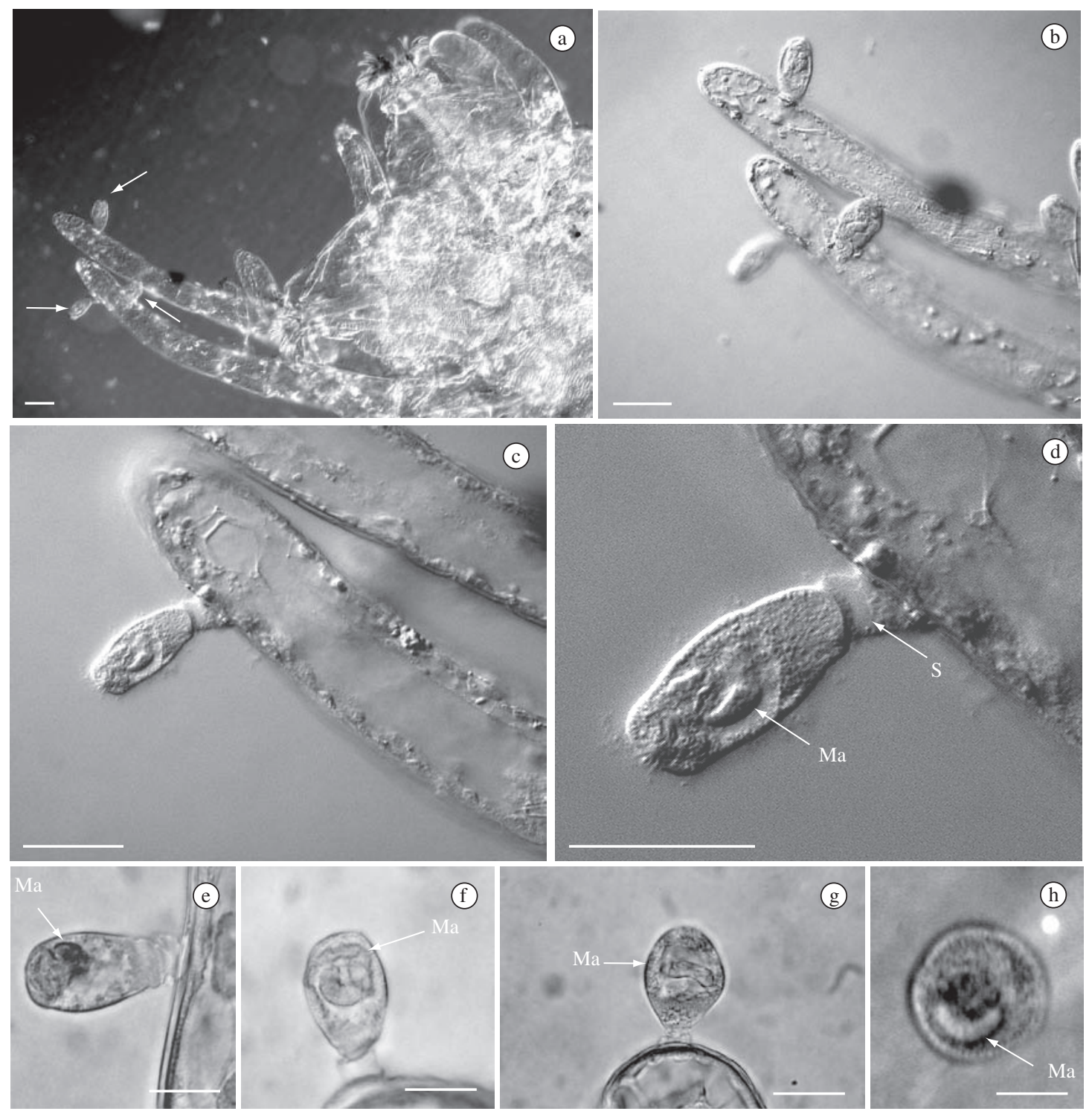

Figure 1. Photomicrographic images of Rhabdostyla chironomi on Chironomidae larvae observed in vivo through DIC (a, d) and bright field (e, h); a) Posterior region of Chironomus decorus group larva showing ciliates in the ventral tubules (arrows); $\mathrm{b}, \mathrm{c}$ ) detail of ventral tubules with ciliates; d) detail of $R$. chironomi showing the stalk (S) and the macronucleus (Ma); e-g) lateral view of $R$. chironomi showing the macronucleus; and h) superior view of $R$. chironom $i$ showing the macronucleus. Bars $(\mathrm{a}, \mathrm{d})=50 \mu \mathrm{m} ;$ and $(\mathrm{e}, \mathrm{h})=25 \mu \mathrm{m}$.

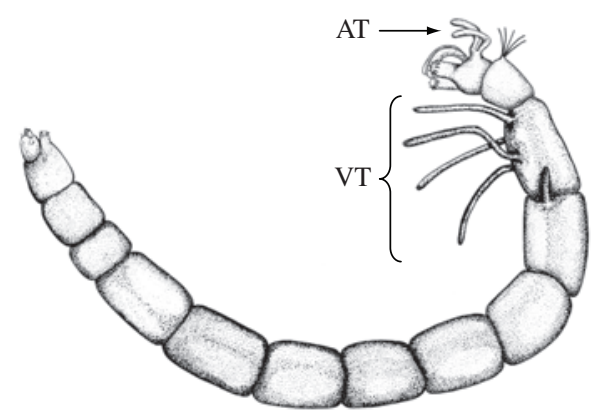

Figure 2. Schematic drawings of Chironomus decorus group larva showing the localization of the ventral (VT) and anal tubules (AT). The ciliates are living on the ventral tubules.
Rhabdostyla present on Foissner and Berger's list of indicator ciliates (1996), and it is an indicator species of the a-mesosaprobity zone, i.e., heavily polluted environments. The high abundance of Chironomus larvae in organically enriched environments increases the living substrate (basibiont) availability, favoring colonization by the ciliates of the species $R$. chironomi (epibiont).

Acknowledgments — We thank Venício Feo da Veiga (Instituto de Microbiologia, UFRJ) for access to the optical microscopy equipment (DIC) and Sthefane D’ávila for the drawing work. This research was supported by FAPEMIG (CRA-1291/05. 2005). 


\section{References}

ARMITAGE, PD., CRASTON, PS. and PINDER, LCV. (Eds.), 1995. The Chironomidae: the Biology and Ecology of NonBiting Nidges. Chapman and Hall, London. 572p.

FENCHEL, T., 1987. Ecology of Protozoa. The biology of freeliving phagotrophic protists. Berlin and Tokyo, Springer, 197p.

FERNANDEZ-LEBORANS, G. and TATO-PORTO, ML., 2000. A review of the species of Protozoan Epibionts on Crustaceans. I. Peritrich ciliates. Crustaceana, vol. 73, no. 6, p. 643-683.

FOISSNER, W. and BERGER, H., 1996. A user-friendly guide to ciliates (Protozoa, Ciliophora) commonly used by hydrobiologists as bioindicators in rivers, lakes, and waste waters, with notes on their ecology. Freshw. Biol., vol. 35, no. 2, p. 375-498.

HENEBRY, MS. and RIDGEWAY, BT., 1979. Epizoic ciliated protozoa of planktonic copepods and cladocerans and their possible use as indicators of organic pollution. Trans. Am. Microsc. Soc., vol. 98, no. 4, p. 495-508.

KAHL, A., 1935. Peritrichia und Chonotricha, p. 651-885. In Urtiere oder Protozoa, Gustav Fischer.

MAYEN-ESTRADA, R. and ALADRO-LUBEL MA. A., 2001. Epibiont Peritrichids (Ciliphora: Peritrichida: Epistylidae) on the crayfish Cambarellus patzcuarensis in lake Pátzcuaro, Michoacán, Mexico. J. Crust. Biol., vol. 21, no. 2, p. 426-434.

MERRITT, RW. and CUMMINS, KW., 1984. An introduction to the Aquatic Insects of the North America. Dubuque, Kendall/ Hunt Publish Company, 772p. Dubuque.

NENNINGER, U., 1948. Die Peritrichen der Umgebung von Erlangen mit besonderer Berücksichtigung ihrer Wirtsspezifität. Zool. Jahrb. Syst., vol. 77, no. 3/4, p. 169-266.

PRECHT, H., 1935. Epizoen der Kieler Bucht. Nova Acta Leopold., vol. 3, no. 15, p. 405-475.

REGALI-SELEGHIM, MH. and GODINHO, MJL., 2004. Peritrich epibiont protozoans in the zooplancton of a subtropical shallow aquatic ecosystem (Monjolinho Reservoir, São Carlos, Brazil). J. Plankton Res., vol. 26, no. 5, p. 501-508.

RIGHI, G., 1973. On Pristina minuta (Oligochaeta, Naididae) from Brazilian soil and its Epizoic Rhabdostyla pristinis sp. n. (Ciliata, Epistylidae). Zool. Anz. Leipzig, vol. 191, no. 5/6, p. 295-299.

SLEIGH, M., 1988. Protozoa and other Protists. New York, Chapman and Hall, 399p.

WAHL, M., 1989. Marine Epibiosis. I. Fouling and Antifouling: some basic aspects. Mar. Ecol., Prog. Ser., vol. 58, p. 175-189. 